\title{
GENDER UNDER-REPRESENTATION IN TEACHING: A CASUALTY OF THE FEMINISATION OF TEACHING?
}

\author{
N. Davids* \\ e-mail: nur@sun.ac.za / https://orcid.org/0000-0002-7588-5814

\section{Y. Waghid*} \\ e-mail: yw@sun.ac.za / https://orcid.org/0000-0003-2565-824X \\ ${ }^{*}$ Department of Education Policy Studies \\ Stellenbosch University \\ Stellenbosch, South Africa
}

\section{ABSTRACT}

Much has been written on the relationship between gender and schooling, and teaching. In particular, the focus has been on the significant dis-proportion between female and male teachers, which remarkably, inverts in relation to educational leadership positions. Arguments abound as to the social factors and hegemonies, which have created not only what is referred to as the "feminisation of teaching", but the risks associated with feminised classrooms and pedagogies, particularly, in relation to boys. Not surprisingly, therefore, an equally dominant narrative calling for the (re)masculinisation of teaching has gained increasing momentum. The basis for this argument is not limited to a seeming need for male teachers as role-models. More disturbing, is the idea that the standing of the profession - invariably measured in terms of salary - might improve if more males are encouraged to become teachers. Our interest in this article is in the patriarchal hegemonies, which give shape to constructions of teaching as "women's work" in the first place. We argue, that rather than contributing to what has been an overdue preoccupation gender-based socialisations, the concern should be on ensuring that teaching transcends framings of "feminisation" and "masculinisation" so that it serves all teachers and all learners.

Keywords: feminisation, masculinisation, gender, teaching, under-representation

\section{TEACHER GENDER}

The literature is replete with competing views on whether or not males and females are motivated by different reasons or factors to become teachers; whether they conceive of, and perceive teaching differently, and indeed, whether teaching differs in relation to the gender of teachers. In identifying a "teacher personality", Coulthard and Kyriacou (2002), for example, suggest that the perception of teaching does not differ between male and female entrants to the 
profession. By contrast, according to Ashby, Hobson, Tracey, Malderez, Tomlinson, Roper, Chambers and Healy (2008), males and females differ in their motivation to become teachers. While female teachers, may be more motivated by the perceived intrinsic aspects of primary teaching, or value the ability to combine teaching with parenthood, males, they assert, may emphasise perceived extrinsic aspects and may be deterred by associations of teaching, especially at primary level, with mothering (Ashby et al. 2008, 6).

Other studies found that females tend to choose the teaching profession somewhat earlier in their lives than men do; teaching is often not the first choice of males (Montecinos and Nielsen 1997). Moreover, state Montecinos and Nielsen (1997), although both men and women appear to choose the profession for rather altruistic reasons, namely to work with children, taskexclusive motives such as salary and the prestige of the profession appear to be more important to men. Where differences arise between how male and female teachers are perceived by learners, women are often held in higher regard than are men (Leone-Perkins et al. 1999). While there is little evidence, contend Sabbe and Aelterman $(2007,527)$ that the gender of teachers has any effect on the achievement of learners, there is some evidence that girls develop more positive attitudes towards, for instance, mathematics or other traditionally non-typical female subjects when they are taught by a female teacher (Li 1999). Seemingly, there is dissensus on whether the gender of teachers has an influence on learners, or their academic performance. Sabbe and Aelterman $(2007,527)$ contend that, "sex difference research" has not been able to uncover clear differences between male and female teachers, which, according to them "supports the constructionist thesis that it is almost impossible to ascribe certain characteristics and effects to individuals exclusively based on their biological sex without considering the social and cultural context and the individuals' personal gender constructions". To Kelly and Nihlen (1982, 173), however, "working-class girls of color" receive the least attention and have the lowest expectations from teachers; there is evidence that teachers tend to prefer "white middle-class girls to black working-class boys".

The dominant presence of females in teaching - particularly at primary school level - have raised concerns about the "feminization" of teaching (Acker 1995, 100). That is, the main concern for the profession, as raised by McNamara (1986, 21, cited in Acker 1995, 100), is that if comes to be seen increasingly as "women's work" then the brute facts of life are such that it will influence social and political attitudes towards teachers. Similar arguments are leveraged by Budge (1994, 12, cited in Acker 1995, 99), the overwhelming presence of female teachers is rendering school staff-rooms as "no go" areas to men. Budge (1994, 12, cited in Acker 1995, 99) asserts that the comparatively low number of male teachers could be ascribed to low salaries in comparison with other professions, and the possibility that women simply "like children 
more". Furthermore, contends Budge (1994, 12, cited in Acker 1995, 99), female teachers "may have been gradually, and unknowingly, moulding education and assessment to suit their gender". For this reason, as Apple $(1987,58)$ recognises, interventions into the teaching profession, are largely the work of men trying to alter the work of a largely female workforce. Apple's (1987) observation provides further credence to the reality that despite a majority female teaching corps, males lay claim, and hold the positions, which determine the content and direction of the profession.

In the South African context, female teachers outnumber males across primary and high schools, but females are under-represented at leadership (principal) levels. The underrepresentation of women in educational leadership in South Africa is exacerbated by findings that women leave management in the same numbers that they enter (Moorosi 2010).

The tables below reflect the enrolment statistics of BEd (Foundation and Intermediate phase) and PGCE (Senior and FET phase) students at a South African university over a fiveyear period.

Table 1: BEd Programme (Foundation and Intermediate phase): Student enrolment per race and gender (2016-2020)

\begin{tabular}{|l|c|c|c|c|c|c|c|c|c|c|}
\hline \multicolumn{1}{|c|}{ Category } & $\mathbf{2 0 1 6}$ & $\mathbf{2}$ & $\mathbf{2 0 1 7}$ & $\mathbf{\%}$ & $\mathbf{2 0 1 8}$ & $\mathbf{\%}$ & $\mathbf{2 0 1 9}$ & $\mathbf{\%}$ & $\mathbf{2 0 2 0}$ & $\mathbf{\%}$ \\
\hline White & 658 & 66,53 & 631 & 64,98 & 638 & 64,19 & 590 & 61,78 & 576 & 60,57 \\
\hline Female & 610 & 61,68 & 586 & 60,35 & 585 & 58,85 & 547 & 57,28 & 534 & 56,15 \\
\hline Male & 48 & 4,85 & 45 & 4,63 & 53 & 5,33 & 43 & 4,50 & 42 & 4,42 \\
\hline Coloured & 296 & 29,93 & 303 & 31,20 & 312 & 31,39 & 319 & 33,40 & 314 & 33,02 \\
\hline Female & 219 & 22,14 & 223 & 22,97 & 228 & 22,94 & 234 & 24,50 & 234 & 24,61 \\
\hline Male & 77 & 7,79 & 80 & 8,24 & 84 & 8,45 & 85 & 8,90 & 80 & 8,41 \\
\hline Black African & 31 & 3,13 & 30 & 3,09 & 32 & 3,22 & 29 & 3,04 & 43 & 4,52 \\
\hline Female & 18 & 1,82 & 14 & 1,44 & 15 & 1,51 & 13 & 1,36 & 28 & 2,94 \\
\hline Male & 13 & 1,31 & 16 & 1,65 & 17 & 1,71 & 16 & 1,68 & 15 & 1,58 \\
\hline Indian & 4 & 0,40 & 7 & 0,72 & 7 & 0,70 & 9 & 0,94 & 4 & 0,42 \\
\hline Female & 3 & 0,30 & 5 & 0,51 & 5 & 0,50 & 7 & 0,73 & 1 & 0,11 \\
\hline Male & 1 & 0,10 & 2 & 0,21 & 2 & 0,20 & 2 & 0,21 & 3 & 0,32 \\
\hline Asian & 0 & 0,00 & 0 & 0,00 & 1 & 0,10 & 1 & 0,10 & 3 & 0,32 \\
\hline Female & 0 & 0,00 & 0 & 0,00 & 1 & 0,10 & 1 & 0,10 & 3 & 0,32 \\
\hline Male & 0 & 0,00 & 0 & 0,00 & 0 & 0,00 & 0 & 0,00 & 0 & 0,00 \\
\hline Withheld & 0 & 0,00 & 0 & 0,00 & 4 & 0,40 & 7 & 0,73 & 11 & 1,16 \\
\hline
\end{tabular}




\begin{tabular}{|l|c|c|c|c|c|c|c|c|c|c|}
\hline \multicolumn{1}{|c|}{ Category } & $\mathbf{2 0 1 6}$ & $\mathbf{\%}$ & $\mathbf{2 0 1 7}$ & $\mathbf{\%}$ & $\mathbf{2 0 1 8}$ & $\mathbf{\%}$ & $\mathbf{2 0 1 9}$ & $\mathbf{\%}$ & $\mathbf{2 0 2 0}$ & $\mathbf{\%}$ \\
\hline Female & 0 & 0,00 & 0 & 0,00 & 3 & 0,30 & 6 & 0,63 & 9 & 0,95 \\
\hline Male & 0 & 0,00 & 0 & 0,00 & 1 & 0,10 & 1 & 0,10 & 2 & 0,21 \\
\hline Total & $\mathbf{9 8 9}$ & & $\mathbf{9 7 1}$ & & $\mathbf{9 9 4}$ & & $\mathbf{9 5 5}$ & & $\mathbf{9 5 1}$ & \\
\hline
\end{tabular}

Table 2: PGCE Programme: Student enrolment per race and gender (2016-2020)

\begin{tabular}{|l|c|c|c|c|c|c|c|c|c|c|}
\hline \multicolumn{1}{|c|}{ Category } & $\mathbf{2 0 1 6}$ & $\mathbf{\%}$ & $\mathbf{2 0 1 7}$ & $\mathbf{\%}$ & $\begin{array}{c}\text { Per } \\
\text { race } \\
\mathbf{2 0 1 8}\end{array}$ & $\mathbf{\%}$ & $\mathbf{2 0 1 9}$ & $\mathbf{\%}$ & $\mathbf{2 0 2 0}$ & $\%$ \\
\hline White & 122 & 67,78 & 115 & 60,85 & 141 & 59,00 & 112 & 48,91 & 128 & 45,39 \\
\hline Female & 95 & 52,78 & 90 & 47,62 & 120 & 50,21 & 90 & 39,30 & 101 & 35,82 \\
\hline Male & 27 & 15,00 & 25 & 13,23 & 21 & 8,79 & 22 & 9,61 & 27 & 9,57 \\
\hline Non-binary & & 0,00 & & 0,00 & 0 & 0,00 & 0 & 0,00 & 1 & 0,35 \\
\hline Coloured & 44 & 24,44 & 67 & 35,45 & 76 & 31,80 & 80 & 34,93 & 100 & 35,46 \\
\hline Female & 30 & 16,67 & 51 & 26,98 & 58 & 24,27 & 57 & 24,89 & 71 & 25,18 \\
\hline Male & 14 & 7,78 & 16 & 8,47 & 18 & 7,53 & 23 & 10,04 & 29 & 10,28 \\
\hline Non-binary & & 0,00 & & 0,00 & 0 & 0,00 & 0 & 0,00 & 0 & 0,00 \\
\hline Black African & 12 & 6,67 & 4 & 2,12 & 19 & 7,95 & 32 & 13,97 & 48 & 17,02 \\
\hline Female & 9 & 5,00 & 1 & 0,53 & 12 & 5,02 & 20 & 8,73 & 28 & 9,93 \\
\hline Male & 3 & 1,67 & 3 & 1,59 & 7 & 2,93 & 12 & 5,24 & 20 & 7,09 \\
\hline Non-binary & & 0,00 & & 0,00 & 0 & 0,00 & 0 & 0,00 & 0 & 0,00 \\
\hline Indian & 2 & 1,11 & 3 & 1,59 & 2 & 0,84 & 3 & 1,31 & 1 & 0,35 \\
\hline Female & 2 & 1,11 & 2 & 1,06 & 2 & 0,84 & 3 & 1,31 & 1 & 0,35 \\
\hline Male & 0 & 0,00 & 1 & 0,53 & 0 & 0,00 & 0 & 0,00 & 0 & 0,00 \\
\hline Non-binary & 0,00 & 0 & 0,00 & 1 & 0,42 & 2 & 0,87 & 5 & 1,77 \\
\hline Withheld & 0 & 0,00 & 0,00 & 1 & 0,42 & 2 & 0,87 & 3 & 1,06 \\
\hline Female & 0 & 0 & 0,00 & 0 & 0,00 & 0 & 0,00 & 0 & 0,00 \\
\hline Male & 0,00 & 0 & 0,00 & 0 & 0,00 & 0 & 0,00 \\
\hline Non-binary & 0 & $\mathbf{1 8 9}$ & & $\mathbf{2 3 9}$ & & $\mathbf{2 2 9}$ & & $\mathbf{2 8 2}$ & \\
\hline Total & & & & & & & & \\
\hline
\end{tabular}

Evident from the above is that current trends of female teachers as a majority corps are being maintained in new student enrolments. While 85.1 per cent of students entering the BEd programme (which is geared at primary school teaching) were female, only 14 per cent were male. Across the same period, the PGCE student composition (who generally teach at high 
school level) comprises 76.3 per cent females, 23.6 per cent males, and 0.087 per cent nonbinary. In both the BEd and PGCE student intakes, the difference between the number of females and males is significant, with a significant difference between male students opting teaching at the primary level, and those opting for high school teaching. Seemingly, while there is a gradual increase in the number of male students entering the PGCE programme, and hence, high school teaching, particularly between 2019 and 2020 - from 57 to 78 students, the BEd programme has seen a decline from 157 students (in 2018), to 147 (in 2019), and 142 (in 2020).

\section{TEACHING AS “FEMINISATION”}

While the concept of an "ethics of care" is commonly associated with the work of Carol Gilligan (1982), it is Nel Noddings (1995), who has used this concept in relation to schooling, teaching, as well as educational leadership. Both Gilligan's (1982) and Noddings (1995), have been subjected to feminist critique for its essentialist implications - namely, that caring is the primary occupation of women, or that women are inherently more suited to caring and therefore more suited to working with young children. Noddings (1995), however disagrees. Instead, she acknowledges that an "ethics of care" can be interpreted as "feminine" in the sense that it represents "an articulation of one important facet of females' experience", the caring approach, however, "is more likely to arise from experience that includes direct, hands-on responsibility for others" (Noddings 1995, 189). Stated differently, it is more likely for women to be associated with the concept of caring, since women are more likely to be the primary carers of children. And yet, of course, any individual or teacher can develop caring by, and through having to care for others.

Furthermore, not all women are good carers, or have a desire to be carers or mothers, in the same way that some men prefer to be home-based and the primary carer, as opposed to being the primary breadwinner. In this regard, gender-specific socialisation might constrain both men and women. On the one hand, women might believe and buy into traditional conceptions of themselves as primary carers, and hence as teachers, and not aspire to occupy positions of leadership or administrators, such as curriculum designers, institutional managers or directors. On the other hand, men might be deterred from pursuing a teaching profession not because of a disinterest or low pay, but because of stereotypes, which frame teaching as "women's work", and instead, assume implicit leadership skills and aptitudes for which they might neither be capacitated, nor desire. It is possible, says Skelton $(2002,85)$, to identify three distinct, but often overlapping ways in which the phrase the "feminisation of primary teaching" is employed: statistical - to indicate the number of women teachers in relation to men teachers; cultural - where the teaching environment is seen to be biased towards females; and political - 
"backlash" politics.

However, continues Skelton $(2002,86)$, the "feminisation of teaching" is often used to imply that there have been fundamental, widespread effects on primary pedagogy and culture caused by the predominance of women teachers. Included, in such discussions are the ideas that:

- daily routines and practices favour females;

- teachers (female) hold low expectations of boys' abilities;

- the absence of male role models creates problems for boys in terms of motivation, discipline and social interaction;

- the way in which the curriculum is delivered and assessed favours girls' learning styles

- that feminism has created an alleged shift towards the privileging of female learning styles, assessment practices, modes of discipline and so forth (Skelton 2002, 86).

The disruption of notions of the "feminisation of teaching" hinges on contesting constructions of gender-specific socialisation - that which not only relies on binary constructions of gender, but couches these constructions as dichotomies. In other words, in order for males to be associated with strength, confidence, and power, women have to be rendered as weak, unconfident and powerless. To Blackmore (1999, 3), the "troubling of dominant masculinities", should not only be understood in relation to women assuming and changing positions of leadership that traditionally have been associated with men; it should also be understood as the troubling of the traditional positioning of men. One of the major concerns arising from genderspecific socialisation, is that both males and females buy into, and perpetuate taken-for-granted assumptions not only about schools as a "feminised" space, but about the idea that "feminisation", can, and ought to be countered with an increase in "masculinity" - that is, by employing more male teachers. A study, conducted by Skelton $(2002,79)$ focused specifically on the views of the female student, because female teachers, as a group, "have generally been more aware and supportive of strategies to reduce gender discrimination and which promote equal opportunities than men teachers, as a group". Despite this initially held view, Skelton $(2002,80)$ found that the attitudes and opinions of the female students in the study "suggested that conventional notions of masculinity and femininity, particularly in relation to teaching roles and responsibilities, retained a firm hold and were, to a large extent, supported". All students were in agreement with the statement that male teachers have a crucial part to play in fostering positive attitudes to study among young boys; more male teachers were needed as role models in the primary school (Skelton 2002). 
Moreover, reports Skelton (2002, 81), "female students specified three conditions associated with traditional masculinity and male power that might be used in order to encourage more men into primary teaching: status and pay; men as knowledge/skills experts (and being 'not feminine'); men as leaders (in control)". That these same female students would not demand similar conditions for themselves, provides significant insights into the embeddedness of patriarchy and its traditional associations with hegemonies of power. These hegemonies of power are equally on display when some female teachers turn to male teachers to deal with "discipline" problems with learners - implying a correlation between physical (male) strength and the ability to "control" a class or a learner. Sometimes, contends Michael Apple $(1987,60)$, the very tasks associated with a profession reinforce sex-typing or gender-specific socialisation:

\footnotetext{
"Since teaching, for instance, does have a service and nurturing component to it, this reconstitutes in action the definition of it as women's work. And given 'our' association of service and nurturing activity as less skilled and less valued than other labor, we thereby revivify patriarchal hierarchies .... In many ways, the very perception of an activity is often saturated with sexual bias. Women's work is considered somehow inferior or of less status simply due to the fact that it is women who do it."
}

To Noddings $(1992,65)$, the problem is not that women constitute the majority of teachers in most contexts, the problem is that the standard not only in education, but in policy, generally, is that of the male experience. Instead of asking why women lag behind men in mathematics, contends Noddings $(1992,66)$, "we might ask why men lag behind women in early childhood education, nursing, full-time parenting, and like activities”. Noddings $(1992,67)$ asserts that if women had set the standard when schools were founded, and curriculums designed, perhaps, schools would be giving far more attention to family and developmental studies. If, as is one of the primary contentions, that low salary plays a de-motivating role for men in pursuing careers as teachers, then the question is why work traditionally associated with women is so consistently poorly paid (Noddings 1992). It is hard to avoid the conclusion, argues Noddings $(1992,66)$, that some men devalue work they have never done themselves and do not wish to do.

\section{REPRESENTATION THROUGH THE DISRUPTION OF GENDER-SOCIALISATION}

For a long time, and increasingly, schools in liberal democracies are labelled as "feminised" institutions, which has not only problematically contributed to the characterisation of teaching as "women's work" (McNamara 1986, 21, cited in Acker 1995, 100), but has led to claims of boys' education being damaged (Skelton 2002; Mills, Martino and Lingard 2004). The basis for this disquiet, explains Skelton $(2003,195)$, seems to have arisen from the discussions around boys' underachievement where one of the explanations for the apparent disaffection of 
schoolboys is the "feminisation" of primary schooling. To Skelton $(2003,195)$, there are various ways in which this "feminisation" is perceived to be taking place but the main issue is the predominance of women teachers which has been argued to have led to primary schools favouring girls and girls' learning styles over those of boys. Furthermore, states Skelton (2002, 77), one of the ideas informing the official (British) government position is that today's generation of boys act out traditional "macho" or "laddish" behaviours, as these are regarded as "cool". The message, says Skelton $(2002,77)$, is that these conventional ways of "being male" need to be replaced and somehow an increase in male teachers will provide boys with role models that will enable the development of alternative, and presumably more compliant, forms of masculinity.

Improving the number and presence of male teachers is often - unquestioningly constructed as a positive for male learners. The assumption is that in order for male learners to achieve academically, or excel at sporting codes, to be "disciplined", or become "men", they need to have male role-models (Mills et al. 2004). Now, we are not asserting that male learners do not need male role-models, but we are also not asserting that a positive role model for male learners can only be derived from male teachers. In previous works, for example, we highlighted that while violence between teachers and learners was rife, it was especially prevalent and brutal between male teachers and male learners (Waghid and Davids 2013). The majority of calls for more male teachers, explain Mills et al. $(2004,361)$, "is driven by a culture of blame that attributes boys' lack of success in schools, inter alia, to feminized curricula, assessment regimes and teaching methods and to female teachers". In turn, the idea that male learners will be out of control without a male hand, contend Mills at al. (2004, 363), "implies that the most effective forms of child rearing involve displays of hegemonic masculinity, a stance that clearly valorizes particular forms of masculine domination". To Mills et al. (2004, 360-361), the suggestion that boys need male authority figures, treats female teachers as deficit - "in that there is a supposition that they are not currently up to the job teaching boys".

As a counter to the "feminisation" of schools and, hence, education, arguments have been made for "re-masculinisation" by employing more male teachers (Skelton 2002; Lingard 2003). There are two major concerns, however, with strategies geared at increasing the number of male teachers, merely for the sake of having male representation. On the one hand, state Mills et al. (2004, 358), ideas of a "feminised" and teaching profession creates the impression that schools are not welcoming and inclusive of males, and by implication, also unwelcoming to male learners. Ironically, the idea of a "feminised" teaching profession is seen only as being negative in relation to men, and not women. The use of "feminised", assert Mills et al. $(2004,358)$ seldom recognises that the "feminisation" of teaching has worked against women in salary and 
career terms. On the other hand, the argument for "re-masculination" however, as Skelton $(2003,195)$ argues, assumes that raising the proportion of male teachers will provide boys with positive, work-oriented "role models" is based on notions of gender which have long been challenged; that is, such strategies are underpinned by sex role socialisation theories whereby masculinity and femininity are located solely within male and female bodies respectively. This unidimensional, essentialist way of conceiving of gender has been unsatisfactory in explaining and understanding differences between men and men, and women and women (Skelton 2003, 195).

More recent thinking on gender, according to Skelton (2003, 196), argues for a consideration of the multidimensionality of identity whereby masculinities and femininities are seen as being shaped by social class, sexuality, religion, age, ethnicity and so forth. To Mills et al. $(2004,357)$, this consideration should include attention and mention of the qualities of male teachers, rather than simply focusing on a specific gender. In addition, state Mills et al. (2004), there are critical issues and questions regarding the somewhat dissonant relationship between men and teaching - a relationship, which has, to date, placed men in a significant minority in terms of teaching composition. To Mills et al. $(2004,359)$, it is ironic that, rather than seeking to challenge the ways in the feminized attributes associated with teaching have been devalued, and addressing the consequences of this for women in the teaching profession, the focus has been on making the profession attractive for men, thereby, inadvertently feeding into a male privilege.

Following the above, there is the additional, often avoided concern of what Skelton (2001, 148) describes as the "significance of a heterosexual identity" which is of "particular significance for male primary teachers". Despite repeated calls for males to enter the teaching profession, says Mills (2004), when a male does respond, and that male happens to gay, others are prepared to think him perverted, paedophilic, and certainly wrong-headed in his intent to teach youngsters (King 2004). According to King $(2004,122)$, men teaching young children is a complex problem and challenge for social expectations. On the hand, contends King (2004, 122), teachers are assumed to be asexual, and when for whatever reason they are discovered not to be asexual, it is a problem. On the other hand, he continues, teaching young children is assumed to be "women's work", so when individuals, other than women, attempt to do this work, it creates problems. Despite gay men being perceived as being "like women", maintains King $(2004,122)$, most of society does not want gay men teaching young children. Gay and lesbian teachers are undesirable because it is assumed that they will influence or recruit their students. More to the point, states King $(2004,122)$, gay men are especially troublesome because they are seen as paedophilic. As a result, calls for the diversification, or an increase in 
the number of males as a promotion of diversification, as Mills et al. $(2004,357)$ point out, has not advocated for the recruitment of gay male teachers.

To Mills $(2004,28)$, the focus on male teachers "highlights the ways in which homophobia polices the boundaries of the teaching profession in relation to masculinities". In seeking to understand why fewer men than women enter the teaching profession, what is perhaps needed, according to Mills $(2004,30)$, is a more sexualised analysis of what keeps men out of the classroom. In turn, schools might neither be seen as sexual spaces, nor as a space for discussions about sexuality in general. According to Bhana (2012, 310), however, "Schools are sexualised institutions despite the denial, through which heterosexual domination becomes an organising principle". Heterosexuality, explains Bhana $(2012,310)$, is based on power, and its privilege is marked in schools - "The power and privilege occurs through a sex/gender binary which states that sexual desire occurs only between women and men, and other forms of sexuality are seen to be "deviant"". We noted that the term "non-binary" had only been introduced as a gender category as of 2018. As evident from the data, only one PGCE student had identified as such. Yet, we know, based on our own interactions with the PGCE class, this number is not correct even when limited to 2018 onwards. The dominance of heterosexual norms continues to cast a pervading shadow among pre-service teachers. These norms are embedded not only in constructions of what constitutes normal and acceptable forms of sexuality, but in discourses of religion, ethnicity and culture. And while some might feel "safer" about revealing their sexual identity within a university classroom setting, they know that to do so within South African school settings, would drastically minimise their opportunity for teaching offers.

Representation in terms of gender, therefore, cannot be conceived in terms of binary constructions between males and females. Indeed, the low numbers of males in the teaching profession is a matter of concern - for all learners, and not only males - but not because there is a shortage of males. Rather, the concern pertains to how we understand difference and diversity, and that while there are differences between males, females and members from the LGBTQI communities, there are deeper differences between males, between females, and between LGBTQI individuals. To homogenise the shortage of males is to lose sight of these differences, and to undermine what representation infers. As discussed in this article, there are many reasons - some more complex than others - for the low number of male teachers in schools in most liberal democracies. Merely increasing the number of males is not going to address the label (or stigma) of teaching as "women's work". That teaching is associated with caring, and hence framed as a woman's role, is a commentary on the hegemonies of power, which divides the world into only two genders - that of masculine and feminine. Undoing this stigma calls for a disruption of the patriarchal discourses and norms, which perpetuate 
marginalisation and minimisation of women, in order to centre a male worldview. Secondly, increasing the number of males will not lead to an increase in salary, and hence, a recognition of the unequivocal value of teachers and teaching. As Apple $(1987,58)$ asserted - 35 years ago - “women's paid work has long been subject to rationalizing logics and attempts to gain control over, and teaching is no different". Thirdly, increasing the number of male teachers will not make "men out of boys", or strengthen their academic potential, or make them more "disciplined". Learners - regardless of whether they prescribe to a particular gender construction or not - are in need of teachers, who are committed to teaching, and who are committed to those they teach.

The focus on gender, therefore, is not to make an argument for more male teachers in schools. The focus on gender is to highlight the role of patriarchal hegemonies in relation to the ideological construction and perception of teaching as "women's work". The challenge, therefore, is to ensure that teaching transcends framings of "feminisation" and "masculinisation" so that it serves all teachers and all learners.

\section{SUMMARY}

While we recognised in this article that female teachers outnumber male teachers across geopolitical contexts in liberal democracies, we were not interested in making an argument for an increase in the number of male teachers. Rather, we wished to show how the relegation of teaching as a caring and nurturing profession has been subject to accusations and treatments of "feminisation", which ought to be devalued. We started by paying attention to the discourse of the "feminisation" of teaching, which has been largely used not only to explain the absence of male teachers, but also misconstrued to explain the seemingly academic under-performance of male learners. In this regard, we showed how gender-specific socialisation might constrain all teachers. By drawing on Noddings (1992), we showed that the problem is not that women constitute the majority of teachers in most contexts, the problem is that the standard not only in education, but in policy, generally, is that of the male experience. Following on this, we argued for a disruption of gender-specific socialisation, and contested commonly held views that male teachers are necessarily good to male learners, both in terms of academic achievement and "becoming men". Instead, we maintained that the focus should not be on merely increasing the number of male teachers; the focus should be on disrupting the patriarchal hegemonies, which render teaching as a "feminised" and hence devalued profession.

\section{REFERENCES}

Acker, S. 1995. Gender and teachers' work. Review of Research in Education 21(1995-1996): 99-162. 
Apple, M. W. 1987. "Gendered teaching, gendered labor". In Critical studies in teacher education: Its folklore, theory and practice, ed. T. S. Popkewitz, 57-84. London: The Falmer Press.

Ashby, P., A. Hobson, L. Tracey, A. Malderez, P. Tomlinson, T. Roper, G. Chambers and J. Healy. 2008. Beginner teachers' experiences of initial teacher preparation, induction and early professional development: A review of literature. Research Report no. DCSF-RW076. London: Department for Children, Schools and Families.

Bhana, D. 2012. Understanding and addressing homophobia in schools: A view from teachers. South African Journal of Education 32: 307-318.

Blackmore, J. 1999. Troubling women. Buckingham: Open University Press.

Coulthard, M. and C. Kyriacou. 2002. Does teaching as a career offer what students are looking for? In The crisis in teacher supply: Research and strategies for retention, ed. I. Menter, M. Hutchings and A. Ross. Stoke on Trent: Trentham Books Ltd.

Gilligan, C. 1982. In a different voice: Psychological theory and women's development. Massachusetts: Harvard University Press.

Kelly, G. and A. Nihlen. 1982. Schooling and the reproduction of patriarchy: Unequal workloads, unequal rewards. In Cultural and economic reproduction in education, ed. M. Apple, 162-180. London \& Boston: Routledge \& Kegan Paul.

King, J. R. 2004. The (im)possibility of gay teachers for young children. Theory into Practice 43(2): $122-127$.

Leone-Perkins, M., R. Schnuth and T. Kanter. 1999. Preceptor-student interactions in ambulatory clerkship: Gender differences in student evaluations of teaching, Teaching and Learning in Medicine 11(3): 164-167.

Li, Q. 1999. Teachers' beliefs and gender differences in mathematics: A review. Educational Research 41(1): 63-76.

Lingard, B. 2003. Where to in gender policy in education after recuperative masculinity politics? International Journal of Inclusive Education 7: 33-56.

Mills, M. 2004. Male teachers, homophobia, misogyny and teacher education. Teaching Education 15(1): 27-39.

Mills, M., W. Martino and B. Lingard. 2004. Attracting, recruiting and retaining male teachers: Policy issues in the male teacher debate. British Journal of Sociology of Education 25(3): 355-369.

Montecinos, C. and L. E. Nielsen. 1997. Gender and cohort differences in university students' decisions to become elementary teacher education major. Journal of Teacher Education 48(1): 47-54.

Moorosi, P. 2010. South African female principals' career paths: Understanding the gender gap in secondary school management. Educational Management Administration \& Leadership 38: 547562.

Noddings, N. 1992. The gender issue. Educational Leadership 49(4): 65-70.

Noddings, N. 1995. Philosophy of education. Boulder, CO: Westview.

Sabbe, E. and A. Aelterman. 2007. Gender in teaching: A literature review. Teachers and Teaching: Theory and Practice 13(5): 521-538.

Skelton, C. 2001. Schooling the boys: Masculinities and primary education. Buckingham: Open University Press.

Skelton, C. 2002. The "feminisation of schooling" or "remasculinising" primary education? International Studies in Sociology of Education 12: 77-96.

Skelton, C. 2003. Male primary teachers and perceptions of masculinity. Educational Review 55(2): 195-209.

Waghid, Y. and N. Davids. 2013. Citizenship education and violence in schools: On disrupted potentialities and becoming. Rotterdam: Sense Publishers. 